SHORT REVIEW

\title{
Effect of land use in the upper Mahaweli catchment area on erosion, landslides and siltation in hydropower reservoirs of Sri Lanka
}

\author{
Tilak Hewawasam \\ Department of Natural Resources, Faculty of Applied Sciences, Sabaragamuwa University of Sri Lanka, Belihuloya.
}

Revised: 25 August 2009; Accepted: 16 October 2009

\begin{abstract}
A number of multipurpose reservoirs have been impounded in the Upper Mahaweli Catchment (UMC) mainly to generate hydropower, which contributes to about $40-50 \%$ of the total hydropower production in the country. The natural forest cover of the UMC has been gradually decreased during the last two centuries due to the large-scale deforestation for plantation agriculture. Subsequently, the forest cover in the hill country has been reduced further to a few isolated patches in order to meet the demand for agriculture, developmental activities and human settlements. Today, vegetables are grown extensively on the steep slopes of the UMC without proper land management practices. Consequently, this agriculturally active land is exposed to severe soil erosion and landslides, in parallel with the rapid rate of deforestation.
\end{abstract}

Estimates of the rate of soil loss on hill slopes and sediment yields in the fluvial system of the UMC indicate that the human-mediated activities in the UMC have increased rates of ongoing erosion by $>100$ times over the background rates of natural erosion. Thus, the river Mahaweli and its tributaries carry enormous amounts of sediments during the rainy seasons, both as bed and suspension loads downstream and large amounts are deposited in the multipurpose reservoirs leading to a reduction of their storage capacities. Siltation in hydropower reservoirs could pose a serious threat, leading to the reduction of hydropower generation in the country and a worsening situation could be anticipated in the future. Therefore, proper management of the land by minimizing the in-situ erosion and preserving the detached soil within the catchments through effective conservation measures need to be implemented in order to ensure a steady and continuous power supply from the hydropower resources.

Keywords: Cosmogenic nuclides, erosion, hydropower generation, landslides, land use, siltation.

\section{INTRODUCTION}

\author{
Importance of the Upper Mahaweli Catchment \\ (UMC)
}

Sri Lanka is generously endowed with water resources, having a large number of rivers most of which originate from the Central Highlands. The main source of water is direct rainfall, where a high annual precipitation is experienced in the Central Highlands. The prevailing climatic conditions and the topography of the land have created excellent conditions that are well-suited for the generation of hydropower. Consequently, a number of hydropower plants have been constructed within the country and almost all the power generated for the national grid was from hydro-power resources until 1995 (Figure 1a) ${ }^{1}$. According to statistics, there has been a slight decline in hydropower consumption in the country since 1995 . This is most probably due to the decrease of power generated caused by the reduction of storage capacities in reservoirs (Figure 1b) ${ }^{2}$. This trend is a significant deviation from the normal pattern of hydropower consumption in the world (Figure 1d) ${ }^{2}$. With the rising demand for power from 1995 onwards, the country has had to rely on alternate means such as expensive fossil fuels that have to be imported for generating power. (Figure 1c) ${ }^{2}$. However, a major proportion of Sri Lanka's power supply, about 35-40\% is generated from hydro-power resources (Figure 1a). Importantly, further possibilities still exist to expand the generation of hydropower in the country by utilizing local water resources.

The severe power crisis of 2002, significantly the affected the industrial areas in the country while adversely affecting the economy. One of the major 
reasons for the reduced power supply is the significant recurrent droughts experienced in the country. Drought is a natural phenomenon, caused either by global or regional climatic changes assisted by local impacts. The decrease of water storage capacity of hydro-power reservoirs due to rapid siltation will be one of the main causes for reduction in the power supply of the country in the near future. Proper land management through implementation of soil conservation strategies in the upstream area is very important and will help in maintaining the storage capacities of hydropower reservoirs in the country.

Sri Lanka has 103 river basins of which seventeen are considered large with areas of more than $1000 \mathrm{~km}^{2}$. The Mahaweli takes in the largest volume of water amounting to one seventh of Sri Lanka's total runoff and has a catchment area that covers $15 \%$ of the land in the country ${ }^{3}$. Under the Mahaweli Development Programme, a series of multipurpose reservoirs were constructed along the upstream segment of the Mahaweli, which is in the UMC, to generate hydropower and provide water for large-scale irrigation in the dry-zone and to make settlements for the landless and unemployed population.

The Accelerated Mahaweli Project, which is the largest single development programme carried out by the Sri Lankan government, commenced in 1977 with the intention of managing water by constructing a series of dams along the main trunk of the Mahaweli River. The
Victoria dam is located in the Dumbare valley, closely downstream of the confluence of the main river and the Hulu Ganga tributary (Figure 2). The dam has created a storage reservoir of 730 million $\mathrm{m}^{3}$ with a power generation capacity of $210 \mathrm{MW}$. The Randenigala dam is located about $26 \mathrm{~km}$ downstream from the Victoria and $6 \mathrm{~km}$ upstream from the Minipe anicut. The Randenigala reservoir has the largest storage capacity, possessing a gross storage of 860 million $\mathrm{m}^{3}$. The Rantembe reservoir is relatively small and is located between the Randenigala dam and the Minipe anicut ${ }^{3}$.

According to historical records, the UMC had been covered with natural vegetation before large-scale deforestation took place for plantation agriculture in the $19^{\text {th }}$ century ${ }^{4}$. However, the major portion of land in the $\mathrm{UMC}$ is presently under tea cultivation and is known to generate severe soil erosion ${ }^{5,6}$. With population growth in the hill country, settlements and farming have rapidly expanded to even the steep slopes, thereby worsening the erosion problem. As a result, the hydroelectric reservoirs in the region are under great risk of sedimentation and the agriculturally utilised lands have been losing their productivity at a rapid pace. Due to sedimentation in the drainage systems downstream, flash flooding in the lowlands of Sri Lanka has become a recurrent natural hazard during periods of intense precipitation. The objectives of the present study are to discuss the land use history, erosion patterns and rates and siltation in the
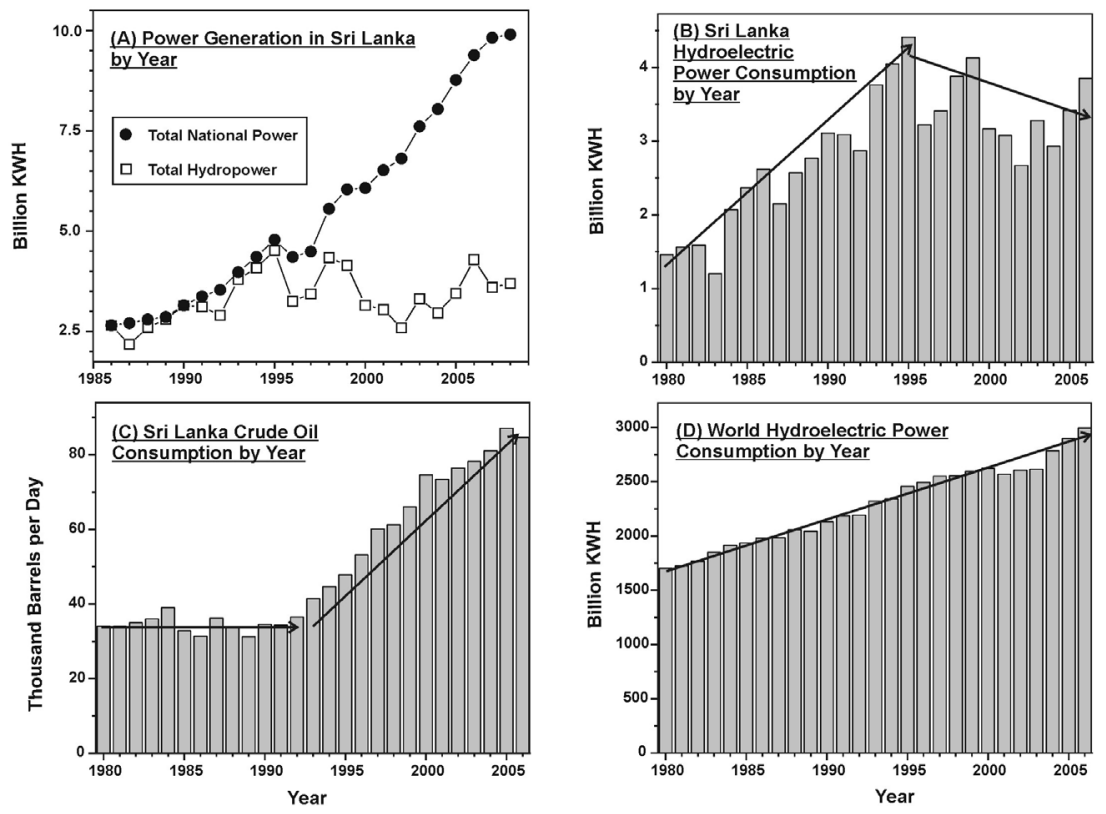

Figure 1: Plots of (A) power generation in Sri Lanka from 1985 to 2008; (B) hydroelectric power consumption in Sri Lanka from 1980 to 2006; (C) crude oil consumption in Sri Lanka from 1980 to 2006 and (D) hydroelectric power consumption in the world from 1980 to $2006^{1,2}$ 
hydropower reservoirs in the UMC, which are important factors when implementing conservation strategies to prevent soil erosion and to maintain the maximum storage capacities of reservoirs.

\section{General characteristics of the UMC}

The UMC has a surface area of $\sim 3120 \mathrm{~km}^{2}$ and a rugged topography, with a mean slope gradient varying from $5^{\circ}$ to $30^{\circ}$. Hard crystalline rocks, mainly granitic in composition, uniformly underlie the catchment. The UMC is located in the wet climatic zone (except for a small patch of intermediate zone). Precipitation is seasonal and heavy with variations from $\sim 1000 \mathrm{~mm} \mathrm{y}^{-1}$ up to $5500 \mathrm{~mm} \mathrm{y}^{-1}$. Five main soil types have been identified within the catchment; Red Yellow Podzolic soils are the dominant type, covering approximately $60 \%$ of the area ${ }^{7}$. The soil is not inherently erodible because of its high infiltration capacity. However, it can cap and compact, leading to impermeable layers that are subjected to high rates of sheet erosion as seen in degraded tea estates ${ }^{8}$.

The UMC had previously been covered with thick forest protecting the land from major erosional processes over thousands or even millions of years. Two types of forests are typical in the area, (i) tropical Lower montane $(900-1500 \mathrm{~m})$ and (ii) tropical Upper

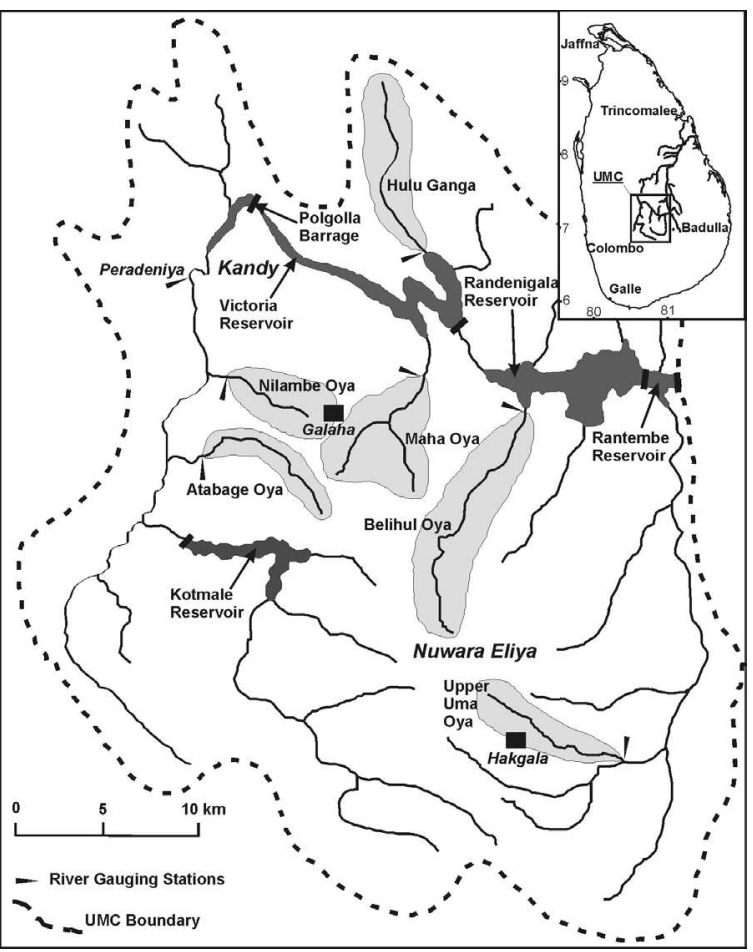

Figure 2: Map of the UMC of Sri Lanka showing the locations of hydropower reservoirs and river-load gauging stations
Montane $(>1500 \mathrm{~m}){ }^{9}$. Deforestation in the last two centuries has resulted in the removal of a large part of forest cover for agricultural usage. At present, natural forest patches have been persevered only on hilltops of the UMC above the 1500 m contour $^{4}$.

\section{Deforestation in the UMC during colonisation}

Early human settlements of Sri Lanka were mostly concentrated in the lowlands, particularly in the dry zone. During the development activities conducted by Singhalese kings, mainly during the $12^{\text {th }}$ century, only a very few settlements were extended to higher elevations, but not above $450 \mathrm{~m}$ contour. Later, during the Portuguese period ( $16^{\text {th }}$ century), the population gradually migrated to the centre of the country but the settlements were still confined to well below the 750 m contour ${ }^{10}$.

For the first time, a large portion of the natural forests in the Central Highlands, where the UMC is located, cleared between 1830 and 1890 with the introduction of coffee under the British administration (Figure 3). The plantations were unevenly distributed with no proper

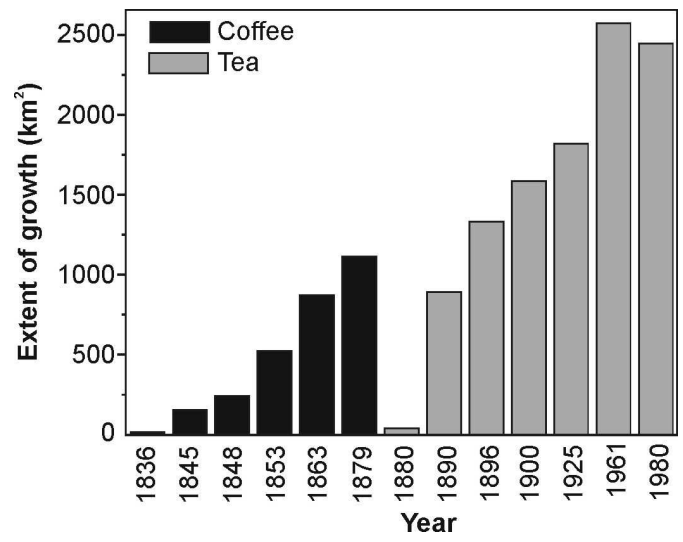

Figure 3: Expansion of (a) coffee and (b) tea plantations in the Central Highlands mainly during the period of colonisation ${ }^{10}$

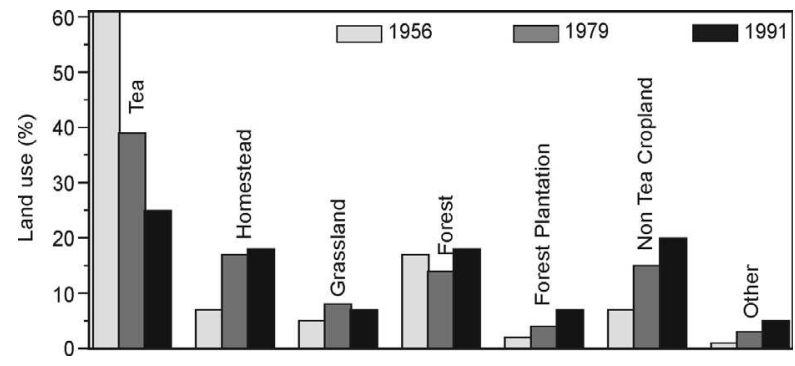

Figure 4: Change in land use in the UMC from 1956 to 1991 (Source: Mahaweli Authority of Sri Lanka) ${ }^{1}$ 
land use policy. The first phase of this deforestation had been continued until the coffee industry declined due to a viral disease in the $1880 \mathrm{~s}$. By that time, the extent of forest that was lost through coffee plantations was as high as $4000 \mathrm{~km}^{2}$ throughout the highlands ${ }^{4}$.

Following the decline of the industry, most of the coffee lands were restored as tea plantations. Due to the low yield, large areas of coffee land were deserted leading to severe soil erosion. Most of these areas are now under grasslands. Plantations of tea and rubber expanded rapidly with the clearance of the remaining forest. It has been estimated that by 1960 about $2500 \mathrm{~km}^{2}$ of the land in the Central Highlands was under tea plantations $(\text { Figure } 3)^{10}$.

During the period of plantation expansion, population density in the Central Highlands increased in two ways; a) by migration of local people from the lowlands to highlands and b) by immigration of indentured labour from southern India. Consequently, human interference in the natural system also increased.

\section{Land use pattern after colonisation}

Deforestation has been continuing due to population growth even after the periods of plantation agriculture. The forest cover of the island rapidly dropped from about $44 \%$ to $24 \%$ during the period from 1956 to 1992 . The average rate of deforestation between 1956 and 1992 was very high and was reported as $\sim 1 \mathrm{~km}^{2}$ per day $^{11}$. Large parts of the forests were cleared to expand towns, villages, and to develop infrastructure facilities. Considerable areas of the forest were also submerged by the hydropower reservoirs that were constructed during the past three decades under the Accelerated Mahaweli Project. In addition to deforestation, the pattern of land use in the country changed extensively during the last four decades due to different agricultural practices. Taken together, both deforestation and changes in land use have caused severe soil erosion in the Central Highlands.

\section{Existing land use pattern and soil erosion in the UMC}

Fragmented patches of natural forest, considered to be pristine, have been preserved at higher elevations of the UMC, such as at Pidurutalagala, Horton Plains, Hakgala, Nilambe and Knuckles. Most of these natural forests (over 90\%) are now protected areas, controlled by the Forest Department and the Department of Wild Life Conservation ${ }^{11}$. Today, the UMC is dominated by tea cultivation that occupies about $25 \%$ of the land area. The rate of soil loss in tea lands is dependent on the agricultural pattern. Lands under seedling tea were identified as the most vulnerable to soil erosion. Replanting of tea by seedlings was the common practice in the Central Highlands. Often, seeds were collected from mother plants that were apparently of high quality. Cultivation and plantation of tea were mostly done along rows on hill slopes. Later on, spaces between rows became channels by the formation of rills and gullies ${ }^{5}$. Frequent weeding further accelerated this process. Nearly $85 \%$ of all tea land in Sri Lanka is under seedling tea ${ }^{5}$. The land use pattern in the UMC has changed to a large extent over a period of three decades from 1956 to 1991 due to changing agricultural demand, development activities and ongoing soil management programmes. A comparison of land use changes for this period is illustrated in Figure 4. As shown, large extents of tea lands have been converted to other uses during this period.

\section{Erosion mechanisms in the UMC}

In addition to the natural or geologic erosion, accelerated erosion occurs in tropics by (i) rill erosion (ii) interill or sheet erosion (iii) gully or ravine erosion, etc. When rain water starts to flow over land surfaces, tiny channels known as rills are formed by eroding the surface linearly. Rills usually occur together and they tend to form on

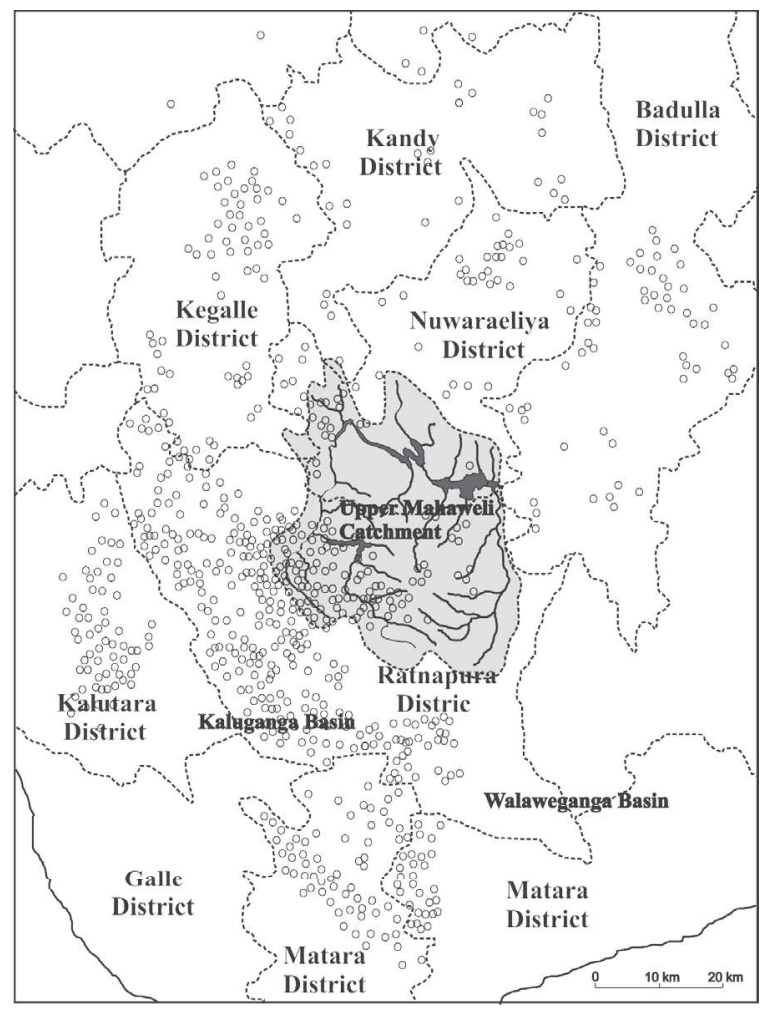

Figure 5: Map of the distribution of landslides, relict landslides and natural landslides scars in the Central Highlands and an overlap of the $\mathrm{UMC}^{12}$ 
slopes. In between the rills, soil is removed as sheets or layers by another form of erosion known as sheet erosion. Widening and deepening of rills finally lead to the formation of gullies, which can be found in highly degraded lands. In the highlands, gully formation also has a distinctive structural control through the preferential erosion along joints, fractures, etc. Erosion that occurs along a stream by rapidly flowing waters is called channel or stream erosion with two distinct components: lateral or stream bank widening (especially during bank full stages) and vertical down cutting. Different types of mass movements are also considered as contributing to erosion. However, their mechanisms are different from other forms of erosion ${ }^{5}$.

A previous study ${ }^{8}$ observed that the UMC has been undergoing rapid soil loss through sheet erosion since plantation agriculture started. Features such as pedestals (columns of soil standing out from the general eroded surface, covered by a cap of resistant material such as a stone layers), root exposures and armour layers (concentration of coarser soil particles on the soil surface) indicate severe sheet erosion in this area. Pedestals usually indicate lands with rates of sheet erosion as high as $5000 \mathrm{t} \mathrm{km}^{2} \mathrm{y}^{-1}$. However, gully (a deep depression or channel in a landscape) formation has also been recognised as an erosion mechanism in poorly maintained agricultural lands. Formation of ravines and gullies is a very common characteristic in lands under seedling tea ${ }^{5}$.

Before the period of colonisation, most Kandyan villages had been concentrated along major river valleys in the island (called riparian settlements). During this era, the forest was cleared for homesteads and shifting cultivation. Terraced rice fields ("paddy") were scattered in some regions of the hills. The paddy fields were set up just below home gardens that consisted of mixtures of trees and bushes/scrubs, which could be considered as the next best alternative to a natural forest ${ }^{4}$. At that time, the damage to the steep slopes and upper catchment areas by Kandyan settlers was negligible since the population density was low. However, shifting cultivation on steep slopes by slash and burn techniques is a highly destructive process that causes severe soil loss by sheet wash. When the land surface is left exposed between planting phases, some landslides could have been triggered due to poor surface drainage.

\section{Distribution of landslides in the UMC}

In Sri Lanka, nine major districts (Badulla, NuwaraEliya, Ratnapura, Kegalle, Kandy, Matale, Kalutara and also Galle and Matara recently) have been identified as landslide prone or landslide-dominated areas, and the UMC covers four of them, namely Nuwara-Eliya, Kandy, Badulla and Matale districts. According to the records maintained by the National Building Research Organization (NBRO), nearly $12000 \mathrm{~km}^{2}$ of the land area of Sri Lanka $(\sim 18 \%)$ is vulnerable to landslides. The Central Highlands of Sri Lanka, which is characterised by a high density of landslide distributions, is the region most prone to landslides due to its rugged topography (Figure 5). The landslide distribution density in the UMC is relatively low when compared to the other large basins such as the Kalu-Ganga, but the quantity of sediments delivered through landslides to the river load in the UMC renders it noteworthy (Figure 5). This is due to the high connectivity of the landslides with the stream networks ${ }^{12}$. According to the author's own observations, enormous amounts of sediments have been dumped into both Randenigala and Rantembe reservoirs by Kurundu Oya, Belihul Oya and Uma Oya, three tributaries in the UMC, as a result of a series of landslides that occurred during heavy rains in the early part of 2007 in Walapane area of the Nuwara-Eliya district. The amounts of sediments delivered to Kurundu Oya, Belihul Oya and Uma Oya by this event were estimated as $84,400 \mathrm{~m}^{3}, 65,000 \mathrm{~m}^{3}$ and $6,500 \mathrm{~m}^{3}$, respectively (unpublished report, Geological Survey and Mines Bureau). Even though landslides are episodic and lasting over a short period, the amount of sediments delivered to the fluvial networks and eventually deposited in reservoirs may be much larger than that resulting from the continuous flow of sediments supplied by other processes of erosion, particularly in areas where landslide density is high. In support of the same view, Gunatilaka ${ }^{12}$ suggested that "naturally occurring" landslides were and are the dominant erosional process in the Central Highlands and play a major role in the slope and escarpment retreat processes of topographic development in the Central Highlands of Sri Lanka under low natural denudation rates.

Relief, lithology, rock structure, and soil type have been identified as natural control mechanisms of landslides. However, human activities have predominantly caused the initiation of recent landslides in Sri Lanka as is evident from the ongoing increase in their frequency and distribution ${ }^{13}$. The frequency of landsliding has dramatically increased during the past few decades as a result of human perturbations. The same study ${ }^{13}$ reported that a large number of recent landslides occurred on slopes in the agricultural areas, based on analysing 200 mass movements in the hill country. Based on a statistical analysis, $35 \%, 20 \%, 10 \%, 13 \%$, and $8 \%$ of landslides occurred in tea, rubber, coconut, paddy and vegetable cultivated lands respectively. 
On-site soil loss measurement derived erosion rates in the UMC

Soil-loss measurements can be obtained at various temporal and spatial scales depending on the purpose of the survey (Figure 6). Rates of soil loss required to develop and monitor the effectiveness of soil conservation in agricultural lands are estimated over short periods, ranging from a single rainstorm to several years. Sediment traps that are installed in agricultural plots on actual hill slopes (on-site sediment traps) are used to monitor soil losses through different vegetation types. This method greatly underestimates the real rates of local soil losses due to dislodging of sediment that is mobilized during high-intensity rainfall or large storm events ${ }^{14}$. As an alternative, field runoff plots are experimentally monitored at the laboratory scale. Laboratory plots can be carefully controlled, and hence rates can be estimated with an improved accuracy ${ }^{14}$. However, laboratory experiments have certain limitations; they do not truly represent field conditions such as influence of soil and plant characteristics on erosion or temporal variations of environmental conditions, and hence the derived measurements are not really representative ${ }^{14}$. Commonly, the Universal Soil Loss Equation (USLE) is used to predict rates of soil loss in croplands as an indirect approach. For USLE, it is assumed that the total soil loss in a specific site depends on rainfall erosivity, soil susceptibility, slope length and steepness, and crop and land management ${ }^{15}$. Even though it is widely applied, the application of USLE is a purely empirical approach and is not based on any real on-site measurements.

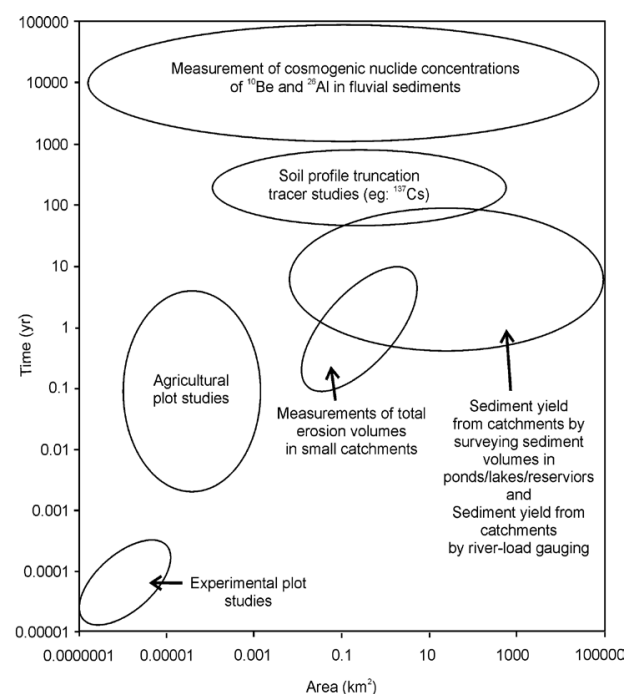

Figure 6: The common techniques that are used to estimate erosion and sediment delivery rates over different temporal and spatial scales (modified after Verstraeten and Poesen ${ }^{39}$ )
A large amount of field data on erosion losses from the UMC has been accumulated in the last few decades; many of them are in unpublished reports at several government institutions. Several of them have been measured directly using on-site sediment traps or at field runoff plots. However, some of the rates have been predicted from the USLE adjusted with parameters more suitable to Sri Lankan conditions. In order to evaluate the magnitude of soil loss, tea lands have been classified into three groups as: (a) seedling tea without any soil conservation (b) seedling tea with some soil conservation and (c) vegetatively-propagated tea. The soil loss from seedling tea plots without any soil conservation is as high as $7500 \mathrm{t} \mathrm{km}^{-2} \mathrm{y}^{-1}$. Soil loss from an unprotected seedling tea land in the up country $(>1000 \mathrm{~m})$ and the mid country (300-600 m) was predicted as $4600 \mathrm{t} \mathrm{km}^{-2} \mathrm{y}^{-1}$ and $1850 \mathrm{t} \mathrm{km}^{-2} \mathrm{y}^{-1}$ respectively, based on the $\mathrm{USLE}^{5}$.

In contrast, soil losses under vegetatively-propagated tea land were as low as $200 \mathrm{t} \mathrm{km}^{-2} \mathrm{y}^{-1}$ (Table 1). One study ${ }^{16}$ reported very low soil loss $\left(24 \mathrm{t} \mathrm{km}^{-2} \mathrm{y}^{-1}\right)$ under a vegetatively-propagated tea plot at Giragama in the mid country $(300-600 \mathrm{~m})$ based on a four-year measurement period. Another study ${ }^{17}$ elaborated on the importance of having a cover crop against surface run-off during replanting of tea. His experiments showed very low soil loss across mulched plots $\left(80 \mathrm{t} \mathrm{km}^{-2} \mathrm{y}^{-1}\right)$ whereas higher soil losses $\left(5200 \mathrm{t} \mathrm{km}^{-2} \mathrm{y}^{-1}\right)$ were reported from unmulched plots, during the same monsoon rainfall conditions. This was further supported by El-Swaify and Krishnarajah ${ }^{5}$, by measuring erosion rates during replanting under different settings. They were 3690-4750 $\mathrm{t} \mathrm{km}^{-2} \mathrm{y}^{-1}$ and 7-35 $\mathrm{t} \mathrm{km}^{-2}$ $\mathrm{y}^{-1}$ in a bare and mulched covered land, respectively ${ }^{5}$.

A previous study also reported high rates of soil loss under seasonal $\operatorname{crops}^{18}$. The experiments, carried out in the Maha Oya catchment of the UMC,

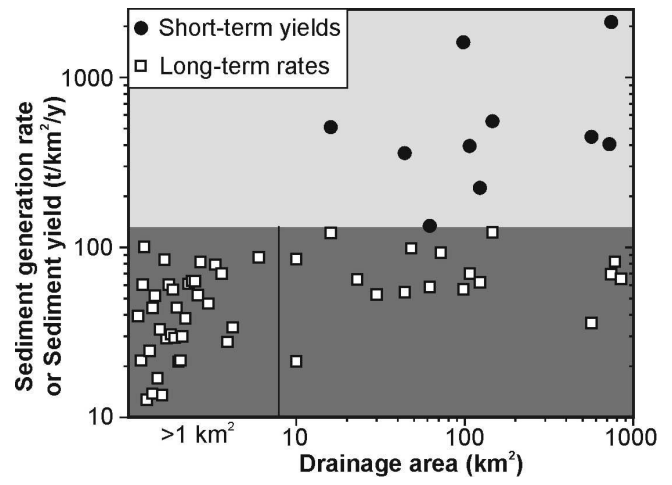

Figure 7: Plot of long-term sediment generation rates (cosmogenicnuclide derived) and short-term sediment yields (river-load gauged) for small and large catchments of the UMC 
revealed that the soil losses under tobacco, capsicum and carrot plots were $7000 \mathrm{t} \mathrm{km}^{-2} \mathrm{y}^{-1}, 3800 \mathrm{t} \mathrm{km}^{-2} \mathrm{y}^{-1}$ and $1800 \mathrm{t} \mathrm{km}^{-2} \mathrm{y}^{1}$, respectively. These quantitative assessments clearly indicate that massive quantities of soil are being removed from poorly managed lands under seedling tea and seasonal crops. Also the results stress the implications of surface cover to control the run-off especially during the replanting of tea. Even though quantitative estimates are not available; it is inevitable that a huge amount of soil is presently being lost through potato and vegetable cultivations on steep slopes in the UMC. These croplands are irrigated by sprinkler methods that detach the soil particles from the ground and are under poor land management. The Ministry of Forestry and Environment has presented the most upto-date compilation of soil erosion rates that are listed in Table $1^{19}$. A team of agricultural engineers and soil scientists of the Ministry of Forestry and Environment reviewed the most accurate estimates of soil loss based on field studies to make this compilation ${ }^{20}$.

\section{River load-gauged erosion rates in the UMC}

Erosion rates are generally inferred from the total load of denudational materials that are transported within streams or rivers (river load gauging). The load includes a sum of the dissolved or solute flux, the suspended particle flux and the bed material or sand flux ${ }^{21}$. River gauging is generally continued over a short-period of time, from a few years to a maximum of few decades. Therefore, the resulting rate of erosion is an average within a period of monitoring, typically 1-100 years (Figure 6). There are many practical difficulties and measurement uncertainties in this approach. River load gauging may not record sediment transported by rivers during low-frequency and high-magnitude events such as floods and mass movements. Further, some sediments may not pass through the gauging station because they are trapped in upstream dams ${ }^{22}$ or stored temporarily within the catchment ${ }^{23,24}$. Therefore, short-term rates are subject to a high degree of uncertainty and cannot necessarily be regarded as a natural rate of erosion.

The suspended load in the Mahaweli River was first measured near the Botanic Gardens, Peradeniya in Kandy (Figure 2$)^{25}$. These preliminarily measurements were carried out merely by collecting surface water samples from a boat and measuring the flow velocity using a current meter. The rates of suspended load varied from 130,000-820,000 $\mathrm{t}^{-1}$, which can be translated into a maximum rate of sediment yield of $11.5 \mathrm{t} \mathrm{km}^{-2} \mathrm{y}^{-1}$, by dividing the catchment's upstream area. However, based on these measurements and assuming a sediment delivery ratio of only $10 \%$, a soil loss of $115 \mathrm{t} \mathrm{km}^{-2} \mathrm{y}^{-1}$ from the upper catchments was documented ${ }^{5}$.

The Netherlands Engineering Consultants monitored the suspended load of the Mahaweli at two locations, at Peradeniya and Weragantota (below the UMC) over the two periods, June-July and October-November 1983 (Figure 2) ${ }^{26}$. In that study, average annual sediment yields were derived for the period of 1950 to 1982 by applying sediment rating curves to monthly discharge. The sediment yield of the UMC above Peradeniya was $420 \mathrm{t} \mathrm{km}^{-2} \mathrm{y}^{-1}$. Two values for sediment loads passing Weragantota were calculated. It was $1,600,000 \mathrm{t} \mathrm{y}^{-1}$ prior to 1975 and $500,000 \mathrm{t} \mathrm{y}^{-1}$ after $1975^{26}$. This difference is due to trapping of sediments at Pologolla and Minipe barrages, which were constructed after 1975. This study indicated that an enormous amount of sediments had been silted in the Pologolla barrage.

The Mahaweli Authority of Sri Lanka with the assistance of H.R. Wallingford Limited, UK has

Table 1: Extent of different land use types and estimated soil erosion rates in the UMC $\mathrm{UM}^{19,20}$

\begin{tabular}{lccc}
\hline Land use type & $\begin{array}{c}\text { Area } \\
\left(\mathrm{km}^{2}\right)\end{array}$ & $\begin{array}{c}\text { Soil loss } \\
\left(\mathrm{t} \mathrm{km}^{-2} \mathrm{y}^{-1}\right)\end{array}$ & $\begin{array}{c}\text { Bedrock } \\
\text { erosion rate } \\
\left(\mathrm{mm} \mathrm{ky}^{-1}\right)\end{array}$ \\
\hline Dense forest & 356.6 & 100 & 37 \\
Degraded forest and scrubs & 435.7 & 2500 & 925 \\
Degraded grasslands & 141.9 & 3000 & 1110 \\
Poorly managed seedling tea & 3454.8 & 5200 & 1924 \\
Seedling tea with some conservation & 252.7 & 1500 & 555 \\
Vegetatively-propagated tea & 114.9 & 200 & 74 \\
Paddy & 285.7 & 300 & 111 \\
Home gardens & 537.7 & 100 & 37 \\
Shifting cultivation and tobacco & 484.6 & 7000 & 2590 \\
Market gardens & 163.6 & 2500 & 925 \\
\hline
\end{tabular}

${ }^{1}$ Converted into corresponding bedrock erosion considering density as $2.7 \mathrm{~g} / \mathrm{cm}^{3}$. 
monitored six tributary catchments (Nilambe Oya, Upper Uma Oya, Hulu Ganga, Maha Oya, Belihul Oya and Atabage Oya) of the Mahweli River for suspended sediment yields and discharge since 1991 (Figure 2) ${ }^{27}$. Sediments yields were measured at the gauging stations by pumping river water/sediment samples at a constant rate, then collecting them into buckets of known volume. Many samples were collected across the stream width at different depths for a single monitoring exercise. The discharge was continuously monitored at the gauging station using an automatic water level recorder. Actual sediment yields were measured only for one to three year periods at frequent intervals. Sediment yields were then derived for more years using sediment rating curves. Total sediment yields derived for these catchments range from 130 to $2100 \mathrm{t} \mathrm{km}^{-2} \mathrm{y}^{-1}$ and are graphically presented in Figure $7^{6}$.

\section{Cosmogenic-nuclide derived erosion rates in the UMC}

Measurement of in-situ produced cosmogenic nuclides in minerals such as ${ }^{10} \mathrm{Be}$ in quartz is now widely used to quantify and characterise rates of erosion and other geomorphological processes. In-situ cosmogenic nuclides, such as ${ }^{10} \mathrm{Be}$ and ${ }^{27} \mathrm{Al}$, are formed within mineral grains at the earth's surface due to bombardment by secondary cosmic rays ${ }^{28}$. For example, atomic nuclei of $\mathrm{Si}$ and $\mathrm{O}$ in mineral quartz interact with secondary cosmic rays generating cosmogenic ${ }^{27} \mathrm{Al}$ and ${ }^{10} \mathrm{Be}$, respectively. Production of in-situ cosmogenic nuclides is greatest at the earth's surface and decreases exponentially with depth below the surface (Figure 8 ) $^{28}$. Therefore, the accumulated nuclide concentration in a mineral grain over the whole period of cosmogenic exposure records the rate at which a specific grain has been exhumed. Hence, cosmogenic concentrations in mineral grains can be used to quantify the rate of erosion. This indirect technique quantifies the total erosion including both chemical and physical components, averaging over a long period, generally in 1000 to 100,000 year time scales (Figure 6).

A study ${ }^{28}$ has shown that the surface nuclide concentration $(\mathrm{N})$ of a steadily eroding bedrock is inversely proportional to the rate of erosion (E), that is $\mathrm{E}=\mathrm{P}_{0} \Lambda / \mathrm{N}$, where $\mathrm{P}_{0}$ is the cosmogenic production rate at the surface and $\Lambda$ is the absorption mean free path (the $1 / \mathrm{e}$ attenuation length for production rate, $\Lambda=\mathrm{ca} .60 \mathrm{~cm}$ for granitic rocks). This equation requires values for $\mathrm{P}_{0}$ and $\mathrm{N}$ to calculate the erosion rate of a rock that erodes steadily. Developments in Accelerator Mass Spectrometry (AMS) have offered the opportunity to measure minute concentrations of in-situ produced cosmogenic nuclides (N) in terrestrial materials. Quartz is commonly used to measure the abundance of ${ }^{10} \mathrm{Be}$ and ${ }^{27} \mathrm{Al}$ for erosion studies since it (i) consists chiefly of cosmogenic targets of $\mathrm{Si}$ and $\mathrm{O}$, (ii) is geologically abundant in almost all types of rocks and relatively easy to separate, (iii) is tight in crystal structure minimising possible contamination by atmospherically derived cosmogenic nuclides, (iv) is simple in target chemistry ( $\mathrm{Si}$ ad $\mathrm{O}$ ) that allows direct theoretical calculations of ${ }^{10} \mathrm{Be}$ and ${ }^{27} \mathrm{Al}$ and (v) is low in aluminium concentration ${ }^{29}$. Generally, about $50 \mathrm{~g}$ of quartz is taken, purified, and then dissolved in strong acids. The $\mathrm{Be}$ and $\mathrm{Al}$ fraction in the sample is separated using ion exchange chromatography ${ }^{30}$ and targets of $\mathrm{BeO}$ and $\mathrm{Al}_{2} \mathrm{O}_{3}$ are prepared. AMS measures ratios of ${ }^{10} \mathrm{Be} /{ }^{9} \mathrm{Be}$ and ${ }^{27} \mathrm{Al} /{ }^{28} \mathrm{Al}{ }^{31}$.

Nuclide production rate $\left(\mathrm{P}_{0}\right)$ at the earth's surface depends on the sampling altitude and latitude ${ }^{32}$. Closer to the equator, shielding of cosmic rays is highest and leads to minimum production of cosmogenic nuclides. However, latitude effect becomes negligible and production is nearly constant over latitudes greater than 60 degrees (high latitude). When the sampling altitude is higher, the cosmic ray flux increases yielding a higher production rate. The production rate at the sea level and high latitude (SLHL) is constant and documented by various studies ${ }^{33,31}$. Lal ${ }^{28}$ and Dunnai ${ }^{34}$ have presented two equations to scale the surface production rates at any altitude and latitude of sampling from the production rate of documented SLHL. It has enabled the surface production rate of ${ }^{10} \mathrm{Be}$ or ${ }^{27} \mathrm{Al}\left(\mathrm{P}_{0}\right)$ at any sampling site with known altitude and latitude to be calculated.

Over the past decade, the cosmogenic nuclidebased technique has been further extended to measure erosion rates on catchment scale. Here the steady state concept is assumed in catchment scale. The input of cosmogenic flux to the catchment is balanced by the output of the total flux through erosion and radioactive decay (Figure 8). The spatially integrated rate of erosion within a catchment is then calculated from cosmogenic nuclide concentrations in quartz in river sediments ${ }^{35,36}$. This rate is also a long-term average that is integrated over the 1000 to $100,000 \mathrm{y}$ time scale ${ }^{28}$ (Figure 6). This long-term erosion rate is dominated by the "natural" preanthropogenic background rate, and responds slightly to changes in erosion rates that act on shorter time scales $^{37,38}$.

A previous study ${ }^{6}$ estimated cosmogenic nuclidederived sediment generation rates on hillslopes at six tributaries (Nilambe Oya, upper Uma Oya, Hulu Ganga, Maha Oya, Belihul Oya and Atabage Oya) and four trunk stream locations in the UMC. These measurements were done at the University of Berne, Switzerland and 
at the AMS facility at the Swiss Federal Institute of Technology Zurich, Switzerland. The suspended loads of these sampling locations have been monitored by the Mahaweli Authority and the Irrigation Department of Sri Lanka over a period of 3-30 years (Figure 2). These large catchments are heavily utilized for agriculture and human settlements and the rates could be interfered with by recent human-caused soil erosion. Therefore, in order to avoid any human-caused interference in cosmogenicnuclide sediment generation rates, they have sampled two small catchments completely covered with natural vegetation (ca. $1 \mathrm{~km}^{2}$, Hakgala and Galaha) (Figure2). These two small catchments are almost identical to the other sampling site in term of relief, climate and lithology. Their best estimates of the pre-anthropogenic sediment generation rates are based on cosmogenic nuclide measurements in samples from creeks and soils at two forest sites (Hakgala and Galaha). The measured rates range from 13-30 $\mathrm{t} \mathrm{km}^{-2} \mathrm{y}^{-1}$ (Figure 7).

\section{Reservoir Siltation in the UMC}

Five reservoirs (Kotmale, Polgolla, Victoria, Randenigala and Rantembe) have been impounded in the UMC during

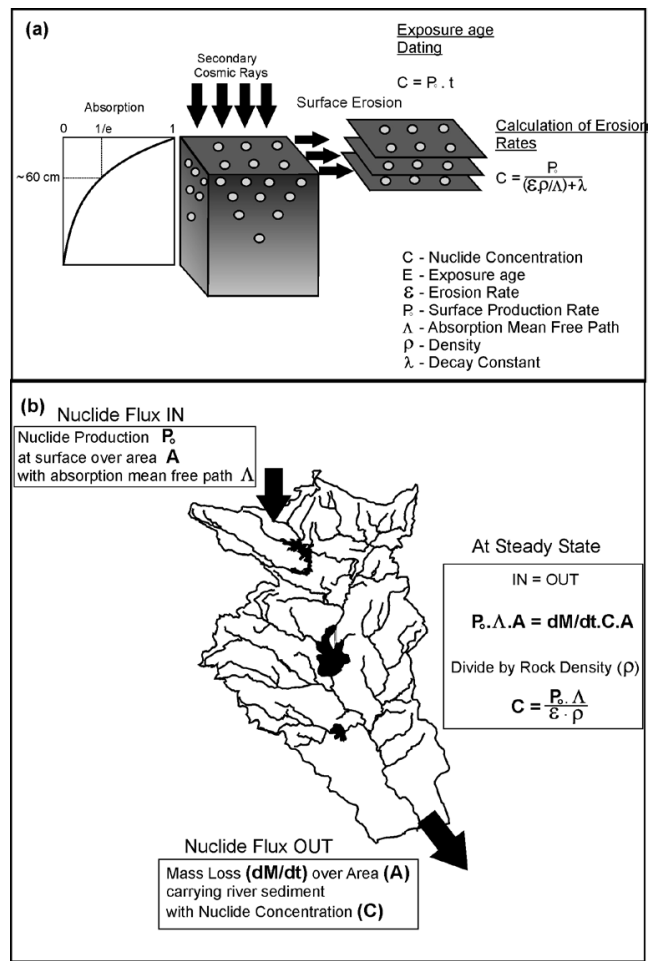

Figure 8: Diagrams illustrating the principles of the cosmogenic nuclide method in (a) estimating exposure age and in-situ erosion rates on rock outcrops, and (b) measuring sediment generation rates in catchment scale (modified after Von Blanckenburg ${ }^{40}$ ) the last few decades to facilitate hydropower and to provide water for agricultural lands in the dry zone. In the 1990s, H.R. Wallinford Limited (UK) completed a hydrographic survey on the reservoirs to determine sedimentation rates and to predict the future sedimentation rates (Table 2). The survey revealed a low sedimentation rate for large reservoirs of UMC (Kotmale and Victoria) for the period from 1985 to 1993 . However, the sedimentation rates in small reservoirs of the UMC (Polgolla and Rantembe) are remarkable. According to the survey, the Polgolla barrage has reduced its storage capacity to $56 \%$ over a 17-year period ${ }^{27}$. More significantly, Rantembe reservoir has reduced its storage capacity to $72 \%$ during a threeyear period after impoundment. Prediction of future sedimentation rates in Rantembe has indicated that its storage capacity will fall to $32 \%$ by the year $2020^{27}$. There are many methods to minimise the rates of siltation in the hydropower reservoirs. However, conservation of soil in the upstream catchments would be the best longterm solution to minimise the rapid rate of sedimentation in the small reservoirs.

The analysis of power generation statistics in the country over the last twenty five years reveals an
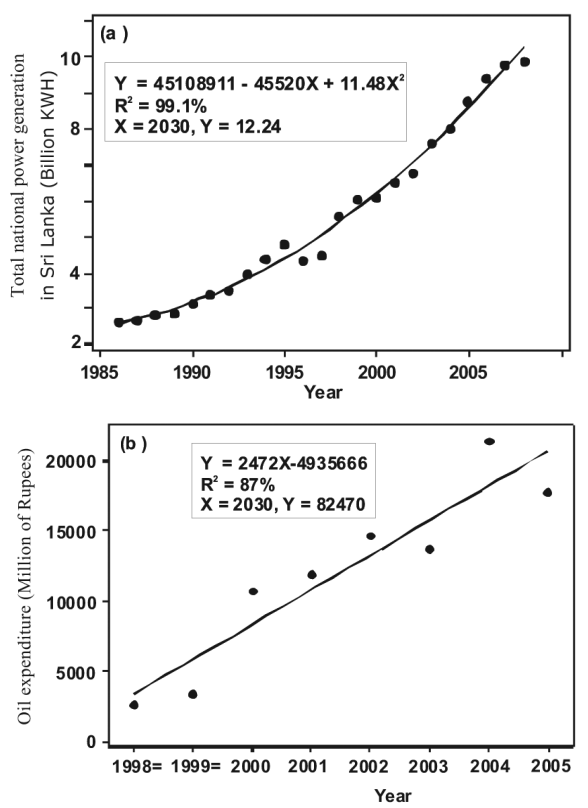

Figure 9: Plots of (a) national power generation in Sri Lanka from 1985 (Data from Statistical Handbook-2008, Mahaweli Authority of Sri Lanka) ${ }^{1}$ and (b) expenditure for oil born by the Ceylon Electricity Board to generate power from 1998 (Annual Report and Accounts-2005, Ceylon Electricity Board $)^{41}$. Note that the estimated power generation and expected oil expenditure in year 2030, under multiple regression analysis, will be 12.24 Billion KWH and 82470 million of rupees per year, respectively. 
Table 2: Original capacity, surveyed capacity and percentage of loss of original capacity due to siltation of hydropower reservoirs impounded in the $\mathrm{UMC}^{27}$

\begin{tabular}{|c|c|c|c|c|c|}
\hline $\begin{array}{l}\text { Name of the } \\
\text { reservoir }\end{array}$ & $\begin{array}{l}\text { Year of the } \\
\text { impoundment }\end{array}$ & $\begin{array}{l}\text { Original capacity } \\
\left(\text { Million } \mathrm{m}^{3}\right)\end{array}$ & $\begin{array}{c}\text { Year of the } \\
\text { hydrographic survey }\end{array}$ & $\begin{array}{c}\text { Surveyed capacity } \\
\left(\text { Million } \mathrm{m}^{3}\right)\end{array}$ & $\begin{array}{c}\text { The loss of original } \\
\text { capacity due to } \\
\text { siltation }\end{array}$ \\
\hline Kotmale & 1985 & 176.770 & 1990 & 184.640 & - \\
\hline Polgolla & 1976 & 5.271 & 1993 & 2.794 & $44 \%$ \\
\hline Victoria & 1985 & 717.530 & 1993 & 713.080 & $01 \%$ \\
\hline Rantembe & 1991 & 10.950 & 1994 & 7.900 & $28 \%$ \\
\hline
\end{tabular}

exponential increase from 1985 to 2008 (Figure 9a) in compliance with the ever increasing demand. This trend, under multiple regression analysis, yields an estimate of 12.24 Billion KWH of energy to fulfill the power demand 20 years from now in 2030 . To accomplish this requirement, the country will require the consumption of crude oil worth Rs. 82,470 million per year, which is a four-fold increase over the recent expenditure (Figure 9b). Since Sri Lanka has not yet exploited any economically feasible fossil fuels, the entire consumption at present relies on oil imports which bears a high cost burden to the national economy. Therefore, it is worthwhile to take maximum benefit from existing hydropower reservoirs by utilizing their full storage capacities and also to expand the use of surface water resources to generate power while establishing more hydropower projects of different scales where environmental conditions are favourable and safe.

\section{CONCLUSION}

Historical records report that the natural forest in the Central Highlands of Sri Lanka was drastically removed for plantation agriculture, human settlements and development activities over the last two centuries. Consequently, the land is exposed to severe soil erosion which contributes to a large amount of sediments to the river tributaries in the Central Highlands. Recent studies on determination of long-term erosion rates in the UMC disclosed very low spatially-averaged natural sediment generation rates on hill slopes that are only about $13-30 \mathrm{t} \mathrm{km}^{-2} \mathrm{y}^{-1}$. These rates could be more comparable to the soil production rates through rock weathering that are only 0.001-0.004 $\mathrm{mm}$ per year. Monitoring of river loads in tributaries in the UMC revealed that spatiallyaveraged short-term sediment yields are as high as 130$2100 \mathrm{t} \mathrm{km}^{-2} \mathrm{y}^{-1}$. Local sediment yields that have been estimated using sediment trap methods in the UMC are even higher and are as high as $100-7000 \mathrm{t} \mathrm{km}^{-2} \mathrm{y}^{-1}$. These quantitative studies imply a 10-100 fold recent increase in spatially-averaged soil erosion or a 250 fold increase in localized soil erosion due to human perturbations. This anthropogenically-intervened soil erosion in the UMC has resulted in a number of negative impacts: namely, decline in soil fertility, reduction in soil depth, rapid siltation of hydropower reservoirs, sedimentation in agricultural-lands, sedimentation in rivers and floods in the lowlands, increasing frequency of landslides, damage to the infrastructure, and the change of water quality of waterways and ecological systems. Out of these, reduction of storage capacities in hydropower reservoirs can be considered as a major disaster since the national power generation in the country is heavily dependent on hydropower. According to the available statistics, the country is presently spending a large amount of national wealth for purchases of crude oil to generate power, and this amount will further increase in the future. Hence it is crucial to maintain the maximum storage capacities of existing hydropower reservoirs. Minimising the dramatic loss of soil, which is a necessary and a non-renewable natural resource, by employing suitable and sustainable conservation strategies should become a major priority.

\section{Acknowledgement}

The National Science Foundation of Sri Lanka is acknowledged for awarding a grant $(\mathrm{RG} / 2005 / \mathrm{DMM} / 04)$ to conduct research on quantification of erosion in the Central Highlands of Sri Lanka. Special thanks go to Friedhelm von Blanckenburg for providing advice to work in geomorphology and surface geochemistry.

\section{References}

1. www.mahaweli.gov.lk. Accessed in June 2009.

2. www.eia.doe.gov. Accessed in June 2009.

3. De S. Hewavisenthi A.C. (1997). Management of the Mahaweli, a river in Sri Lanka. Water International 22(2): 98-107.

4. Wickramagamage P. (1998). Large-scale deforestation for plantation agriculture in the hill country of Sri Lanka and its impact. Hydrological Processes 12(13-14): 20152028.

5. El-Swaify S.A. \& Krishnarajah P. (1983). Soil erosion by water. In: Natural Systems for Development: What 
Planners Need to Know (Ed. R.A. Carpenter ) pp. 99-161. Macmillan Publishing Company, New York.

6. Hewawasam T. (2003). PhD Thesis, Faculty of Natural Sciences, University of Berne, Berne, Switzerland.

7. Department of Irrigation of Sri Lanka (1998). Soil Map of Sri Lanka. Land Use Division, Ministry of Lands and Land Development, Rajamalwatte Road, Battaramulla.

8. Stocking M.A. (1992). Soil Erosion in the Upper Mahaweli Catchment. Environment and Forest Conservation Division, Mahaweli Authority of Sri Lanka, Polgolla.

9. Preu C. \& Erdelen W. (1992). Geoecological consequences of human impacts on forests in Sri Lanka. In: Tropical Forests in Transition (Ed. J. G. Goldammer) pp. 147-164. Birkhauser, Basel, Switzerland.

10. Wickramagamage P. (1990). A man's role in the degradation of soil and water resources in Sri Lanka: a historical perspective. Journal of the National Science Council of Sri Lanka 18(1): 1-16.

11. United Nations Environment Programme, (2001). State of the Environment. UNEP, Nirobi, Kenya.

12. Gunatilaka A. (2007). Role of basin-wide landslides in the formation of extensive alluvial gemstone deposits in Sri Lanka. Earth Surface Processes and Landforms 32(12): 1863-1873.

13. Senanayake K. (1993). Causes and mechanisms of landslides in Sri Lanka. In: Environmental Management, Geo-Water \& Engineering Aspects (Eds. R.N. Chowdhury \& S.M. Sivakumar) pp. 323-326. Balkema, Rotterdam, The Netherlands.

14. Toy T.J., Foster G.R. \& Renard K.G. (2002). Soil Erosion: Processes, Predictions, Measurements, and Control. p. 338. John Wiley \& Sons, New York.

15. http://www.ceb.lk/Publications/Annual\%20Report/ Annual\%20Report\%202005\%20Z.pdf. Accessed in June 2008.

16. Krishnarajah P. (1985). Soil erosion control measures for tea land in Sri Lanka. Sri Lankan Journal of Tea Science 54(2): 91-100.

17. Manipura W.P. (1972). Influence of mulch land cover crops on surface run-off and soil erosion in tea lands in the early growth of replanted tea. Tea Quarterly 42(3): 95102.

18. Krishnarajah P. (1982). Soil erosion and conservation in the Upper Mahaweli Watersheds. Joachim Memorial Lecture, Annual Sessions of the Soil Science Society of Sri Lanka, Colombo.

19. Ministry of Forestry and Environment of Sri Lanka (1995). Forestry Sector Master Plan. Forestry Planning Unit, Ministry of Forestry and Environment, Colombo.

20. Gunatilake H.M. \& Vieth G.R. (2000). Estimation of onsite cost of soil erosion : a comparison of replacement and productivity change methods. Journal of Soil and Water Conservation 55(2): 197-204.

21 Summerfield M.A. \& Hulton N.J. (1994). Natural controls of fluvial denudation rate in major world drainage basins. Journal of Geophysical Research 99(B7): 13871-13883.

22. Milliman J.D. \& Syvitski J.P.M. (1992). Geomorphic/ tectonic control of sediment discharge to the ocean: the importance of small mountainous rivers. The Journal of
Geology 100: 525-544.

23. Trimble S.W. (1999). Decreased rates of alluvial sediment storage in the Coon Creek Basin, Wisconsin, 1975-93. Science 285(5431): 1244-1246.

24. Trimble S.W. \& Crosson P.U.S. (2000). Soil erosion ratesmyth and reality. Science 289(5477): 248-250.

25. Joachim A.W.R. \& Pandittesekere D.G. (1930). A soil erosion investigation. Tropical Agriculturist 74: 200-203.

26. Netherlands Engineering Consultants (NEDECO). (1984). Sediment Transport in the Mahaweli Ganga. Hydrology Division, Irrigation Department, Colombo.

27. Wallingford H.R. (1995). Sedimentation Studies in the Upper Mahaweli Catchment, Sri Lanka. p.40. HR Wallingford Ltd., Oxon, UK.

28. Lal D. (1991). Cosmic ray labelling of erosion surfaces: in situ nuclide production rates and erosion models. Earth and Planetary Science Letters 104(2-4): 424-439.

29. Kohl C.P. \& Nishiizumi K. (1992). Chemical isolation of quartz for measurement of in-situ-produced cosmogenic nuclides. Geochimica et Cosmochimica Acta 56(9): 3583 $-3587$.

30. Von Blanckenburg F., Belshaw N.S. \& O’Nions R.K. (1996). Separation of ${ }^{9} \mathrm{Be}$ and cosmogenic ${ }^{10} \mathrm{Be}$ from environmental materials and SIMS isotope dilution analysis. Chemical Geology 129(1-2): 93-99.

31. Kubik P.W., Ivy-Ochs S., Masarik J., Frank M. \& Schlüchter C. (1998). ${ }^{10} \mathrm{Be}$ and ${ }^{26} \mathrm{Al}$ production rates deduced from an instantaneous event within the dendrocalibration curve, the landslide of Köfels, Oetz Valley, Austria. Earth and Planetary Science Letters 161(1-4): 231-241.

32. Lal D. \& Peters B. (1967). Cosmic ray-produced radioactivity on the earth. In: Handbuch der Physik (Ed. S. Flügge) pp. 551-612. Springer Verlag, Berlin.

33. Nishiizumi K., Winterer E.L., Kohl C.P. \& Klein J. (1989). Cosmic ray production rates of ${ }^{10} \mathrm{Be}$ and ${ }^{26} \mathrm{Al}$ in quartz from glacially polished rocks. Journal of Geophysical Research 94(B12): 17907-17915.

34. Dunai T.J. (2000). Scaling factors for production rates of in situ produced cosmogenic nuclides: a critical re-evaluation. Earth and Planetary Science Letters 176(1): 157-169.

35. Brown E.T., Bourlès D.L., Colin F., Raisbeck G.M., Yiou F. \& Desgarceaux S. (1995). Evidence for muon-induced production of ${ }^{10} \mathrm{Be}$ in near-surface rocks from the Congo. Geophysical Research Letters 22(6): 703-706.

36. Hewawasam T., Von Blanckenburg F., Schaller M. \& Kubik W. (2003). Increase of human over natural erosion rates in tropical highlands constrained by cosmogenic nuclides. Geology 31(7): 597-600.

37. Bierman P. \& Steig E.J. (1996). Estimating rates of denudation using cosmogenic isotope abundances in sediment. Earth Surface Processes and Landforms 21(2): 125-139.

38. Brown E.T., Stallard R.F., Larsen M.C., Bourlès D. L., Raisbeck G.M. \& Yiou F. (1998). Determination of predevelopment denudation rates of an agricultural watershed (Cayaguás River, Puerto Rico) using in situproduced ${ }^{10} \mathrm{Be}$ in river-borne quartz. Earth and Planetary Science Letters 160(3-4): 723-728. 
39. Verstraeten G. \& Poesen J. (2001). Factors controlling sediment yield from small intensively cultivated catchments in a temperate humid climate. Geomorphology 40(1-2): 123-144.

40. Von Blanckenburg F. (2005). The control mechanisms of erosion and weathering at basin scale from cosmogenic nuclides in river sediment. Earth and Planetary Science Letters 237(3-4): 462-479.

41. http://tonto.eia.doe.gov/country/country_energy_data. cfm? fips $=C E$. Accessed in June 2008. 